\title{
Selection index for recommendation of cowpea cultivars for green bean production ${ }^{1}$
}

\author{
Índice para recomendação de cultivares de feijão-caupi aptos a produção de grãos \\ verdes
}

\author{
Leane Fialho de Melo ${ }^{2 *}$, Tamiris Pereira da Silva² ${ }^{2}$ Jéssica Soares Pereira ${ }^{2}$, Júlio César DoVale ${ }^{3}$ and Cândida \\ Hermínia Campos Magalhães Bertini ${ }^{3}$
}

\begin{abstract}
Cowpea is one of the main food crops in the Northeast region of Brazil, thus, breeders have carried out researches to identify genotypes with good production response and attributes that satisfy growers and consumer market demands for green beans and pods. Therefore, the objective of this work was to develop a selection index that assists in the recommendation of cowpea cultivars for green bean production and select the best genotypes based on this index. Twenty cowpea genotypes, including lines and cultivars, were evaluated for eleven characters in five locations in the state of Ceará, Brazil: Acaraú, Pentecoste, Crato, Mauriti, and Madalena. A randomized block design was used, with four replications. The characters evaluated were: number of days for the beginning of flowering (NDF), number of days for maturation (NDM), plant height (PH), green pod length (GPL), number of beans per green pod (NBP), green pod weight (GPW), bean weight per green pod (BWP), one hundred green bean weight (100GBW), bean index (BI), green pod yield (GPY), and green bean yield (GBY). The results of the characters were subjected to analysis of relative importance, estimated by principal component analysis and analysis of factors, and used to develop selection indexes. The following index was obtained: $\mathrm{I}_{3}=0.079 \mathrm{NDF}-0.083 \mathrm{PH}+0.119 \mathrm{GPL}+0.034 \mathrm{GPW}$ $-0.176100 \mathrm{GBW}+0.340 \mathrm{GPY}$. This index indicated that the genotypes MNC05-847B-123, Azulão-MS, MNC00-595F-27, MNC99-541F-15, MNC05-835B-16, and MNC00-595F-2 are the most promising for green bean production.
\end{abstract}

Key words: Vigna unguiculata. Cowpea breeding. Simultaneous selection.

RESUMO - O feijão-caupi é uma das principais culturas alimentícias do Nordeste brasileiro, e por essa razão, melhorista buscam identificar genótipos com boa resposta produtiva e que possuam atributos que satisfaçam as exigências do produtor e do mercado consumidor de grãos e vagens verdes. Desta forma, os objetivos deste trabalho foram elaborar um índice seletivo que permita auxiliar na recomendação de cultivares de feijão-caupi para produção de grãos verdes e selecionar os melhores genótipos com base no mesmo. Para isso, foram avaliados onze caracteres de 20 genótipos de feijão-caupi, incluindo linhagens e cultivares, em cinco localidades no estado do Ceará: Acaraú, Pentecoste, Crato, Mauriti e Madalena. Utilizou-se o delineamento de blocos casualizados com quatro repetições. Os caracteres avaliados foram: número de dias para o início da floração, número de dias para maturação, altura da planta, comprimento da vagem verde, número de grãos por vagem verde, massa da vagem verde, massa de grãos da vagem verde, massa de cem grãos verdes, índice de grãos, produtividade das vagens verdes e produtividade de grãos verdes. Foram realizados análise de importância relativa dos caracteres estudados, estimada por meio do método dos componentes principais, análise de fatores e confecção dos índices de seleção. O seguinte índice foi obtido: $\mathrm{I}_{3}=0,079 \mathrm{NDIF}-0,083 \mathrm{ALT}+0,119 \mathrm{COMPV}+0,034 \mathrm{MV}-0,176 \mathrm{M}_{100} \mathrm{G}+0,340 \mathrm{PV}$. Esse índice indicou que os genótipos MNC05-847B-123, Azulão-MS, MNC00-595F-27, MNC99-541F-15, MNC05-835B-16 e MNC00-595F-2 são os mais promissores para produção de grãos verdes.

Palavras-chave: Vigna unguiculata. Melhoramento do caupi. Seleção simultânea.

DOI: $10.5935 / 1806-6690.20210043$

Editor-in-Chief: Eng. Agrônomo Dra. Ana Kelly Firmino da Silva - kelly.firmino@ufc.br

*Author for correspondence

Received for publication on 18/03/2020; approved on 25/09/2020

${ }^{1}$ Part of the first author's doctoral thesis presented to the Graduate Program in Agronomy/Plant Production Science, Federal University of Ceará (UFC)

${ }^{2}$ Graduate Program in Agronomy/Plant Production Science, Federal University of Ceará (UFC), Fortaleza, CE, Brazil, leane_fialho@yahoo.com.br (ORCID ID 0000-0003-2500-0712), tamirisjua@gmail.com (ORCID ID 0000-0002-8356-0809), jessicasoaresp99@gmail.com (ORCID ID 0000-0002-1662-7591)

${ }^{3}$ Department of Plant Production Science, Federal University of Ceará (UFC), Fortaleza, CE, Brazil, juliodovale@ufc.br (ORCID ID 0000-0002-3497-9793), candida@ufc.br (ORCID ID 0000-0003-2949-5660) 


\section{INTRODUCTION}

Cowpea [Vigna unguiculata (L.) Walp.] is an important crop in several countries, such as Brazil, Nigeria, Niger, Burkina Faso, and Namibia, and is a good source of employment and income by presenting low production cost. It is a versatile crop, presenting adaptation to different environmental conditions, mainly to those in tropical regions, such as the North and Northeast regions of Brazil. In addition, the production in these regions have contributed to Brazil becoming the main cowpea producing country in America and the fourth in the world (FREIRE FILHO et al., 2017).

Brazil has three market sectors for cowpea: dry beans, green beans (green pods and beans), and seeds (FREIRE FILHO et al., 2011). The demand for green pods and beans (immature beans) is growing and gaining importance in the market, since it can be produced as a vegetable during the whole year (SILVEIRA et al., 2014). Ceará is the highest cowpea producing and consuming state in Brazil (COMPANHIA NACIONAL DE ABASTECIMENTO, 2018).

Cowpea green bean is characterized by pods close to maturation, with bean moisture of $60 \%$ to $70 \%$ (OLIVEIRA et al., 2001). The beans are harvested and used for consumption by growers, or marketed as green pods or threshed beans (ANDRADE et al., 2010). The green bean market is important for the Northeast region and for many locations in the North, Southwest, and CentralWest regions of Brazil (SOUSA et al., 2015). It is a viable alternative for family farmers and agrobusiness because of its attractive prices for growers, and a business option due to possible advances in industrial processing, for canning, cooling, and freezing products (SILVA; ROCHA; MENEZES JÚNIOR, 2016).

The selection process focused on obtaining cultivars for green cowpea bean and pod markets identifies genotypes with good yield that have attributes that satisfy the demands of growers and consumer markets, such as precocity, uniform maturation, attractive and well-developed pods, easy threshing, nutritional quality, and post-harvest preservation time. Therefore, breeders seek to combine several desirable phenotypes in only one genotype; thus, the use of a selection index is a good alternative for this purpose.

Selection index is an additional character established by the optimal combination of different characters, which enables an efficient simultaneous selection of multiple characters (CRUZ; CARNEIRO; REGAZZI, 2014). Selection strategies based on these indexes are advantageous because they have lower costs and are faster than other methods. Moreover, it is a good strategy to be used by cowpea breeding programs with limited human and financial resources (OLIVEIRA et al., 2017).

In this context, the objective of this work was to develop a selection index that assists in the recommendation of cowpea cultivars for green bean production and select the best genotypes based on this index.

\section{MATERIAL AND METHODS}

Five crop value and use tests were conducted in different environments and crop seasons, in the following municipalities of the state of Ceará, Brazil: Acaraú ( $02^{\circ} 53$ 'S, $40^{\circ} 08^{\prime} \mathrm{W}$ and $16.5 \mathrm{~m}$ of altitude) in 2015 ; Pentecoste $\left(03^{\circ} 49^{\prime} \mathrm{S}\right.$, $39^{\circ} 20^{\prime} \mathrm{W}$ and $45 \mathrm{~m}$ of altitude), and Crato ( $07^{\circ} 14^{\prime} \mathrm{S}, 39^{\circ} 22^{\prime} \mathrm{W}$ and $427 \mathrm{~m}$ of altitude) in 2016 ; Mauriti $\left(07^{\circ} 23^{\prime} \mathrm{S}, 38^{\circ} 41^{\prime} \mathrm{W}\right.$ and $453 \mathrm{~m}$ of altitude), and Madalena ( $04^{\circ} 47^{\prime} \mathrm{S}, 39^{\circ} 39^{\prime} \mathrm{W}$ and $353 \mathrm{~m}$ of altitude) in 2017. Twenty cowpea genotypes were evaluated; they were superior lines and cultivars belonging to the commercial subclasses Branca, Canapu, Azulão, Verde, and Sempre Verde, which were acquired from the Active Germplasm Bank and Cowpea Breeding Program of the Embrapa Mid-North (Table 1). Vagem Roxa-THE, AzulãoMS, and Sempre Verde-CE are the main cultivars grown for green bean production, thus, they were used as controls.

The tests were conducted in a randomized block experimental design with four replications. The experimental plot in all the tests had dimensions of $3.2 \times$ $5.0 \mathrm{~m}$, consisted of four 5-meter rows; the evaluation area consisted of the two central rows. The spacing used was $0.80 \mathrm{~m}$ between rows and $0.25 \mathrm{~m}$ between plants within the rows, resulting in 20 pits per row. Four seeds were sown per pit; the seedlings were thinned at 15 days after sowing, leaving only one plant per pit.

The soil was prepared using conventional practices with plowing and harrowing, as needed for each area. Soil fertilizers were applied according to recommendations for the soil of each area, based on soil chemical analyses. Pests and weeds were controlled as needed, using insecticide applications and manual weeding, respectively. The plants were manually harvested as the pods reached the maturation point for green bean marketing, i.e., when the pods were well developed and started to present changes in color hue, considering the individual maturation pattern of each genotype.

The following characters were evaluated in all the tests: number of days for beginning of flowering (NDF), number of days from sowing to flowering of $10 \%$ of the plants in the evaluation area of the plot; number of days for maturation (NDM), number of days from sowing to maturation of $10 \%$ of the pods in the evaluation area of the plot; plant height $(\mathrm{PH})$, mean height $(\mathrm{cm})$ measured from the stem base to the last node of the main branch 
Table 1 - Cowpea genotypes evaluated, their respective parent or origin, and commercial subclasses

\begin{tabular}{|c|c|c|c|}
\hline & Genotype & Parent/Origin & Commercial subclass \\
\hline 1 & MNC00-586F-303-9(1) & Capela $\times$ IT85F-2687 & Green \\
\hline 2 & MNC00-595F-2(1) & BRS-Bragança $\times$ GV-10-91-1-1 & Green \\
\hline 3 & $\mathrm{MNC} 00-595 \mathrm{~F}-27^{(1)}$ & BRS-Bragança $\times$ GV-10-91-1-1 & Green \\
\hline 4 & MNC05-835B-15(1) & MNC00-599F-2 × MNC99-537F-14-2 & Green \\
\hline 5 & MNC05-835B-16 ${ }^{(1)}$ & MNC00-599F-2 × MNC99-537F-14-2 & Green \\
\hline 6 & MNC05-841B-49(1) & MNC00-599F-9 × MNC99-537F-14-2 & Green \\
\hline 7 & $\mathrm{MNC} 05-847 \mathrm{~B}-123^{(1)}$ & MNC00-599F-11 × MNC99-537-14-2 & Green \\
\hline 8 & MNC05-847B-126 (1) & MNC00-599F-11 × MNC99-537-14-2 & Green \\
\hline 9 & MNC99-541F-15(1) & TE93-210-13F $\times$ TE96-282-22G & White \\
\hline 10 & BRS Guariba $^{(2)}$ & IT85F-2687 × TE87-98-8G & White \\
\hline 11 & BRS Tumucumaque ${ }^{(2)}$ & TE96-282-22G $\times$ IT87D-611-3 & White \\
\hline 12 & BRS Xiquexique ${ }^{(2)}$ & TE87-108-6G $\times$ TE87-98-8G & White \\
\hline 13 & Paulistinha $^{(2)}$ & Juazeiro-CE & Canapu \\
\hline 14 & Vagem Roxa-THE ${ }^{(2) *}$ & Teresina-PI & White \\
\hline 15 & Azulão-MS ${ }^{(2) *}$ & Dourados-MS & Azulão \\
\hline 16 & Sempre Verde-CE ${ }^{(2)^{*}}$ & Fortaleza-CE & Sempre-Verde \\
\hline 17 & BRS Aracê $\hat{e}^{(2)}$ & MNC-599F-11 × MNC99-537F-14-2 & Green \\
\hline 18 & Pingo-de-Ouro-1-2(1) & Iguatu-CE & Canapu \\
\hline 19 & $\mathrm{MNC} 02-701 \mathrm{~F}-2^{(1)}$ & TE93-210-13F × (TE96-282-22G × Costelão $)$ & White \\
\hline 20 & MNC99-510F-16-1(1) & Paulista $\times$ TE90-180-88F & Sempre-Verde \\
\hline
\end{tabular}

${ }^{(1)}$ Line; ${ }^{(2)}$ Cultivar; ${ }^{\text {Control }}$

in five plants randomly selected in the evaluation area; green pod length (GPL), mean length (cm) of five pods randomly selected in the evaluation area; number of beans per green pod (NBP), mean number of beans in five pods; green pod weight (GPW), mean weight ( $\mathrm{g}$ ) of five pods; bean weight per green pod (BWP), mean bean weight $(\mathrm{cm})$ of five pods; one hundred green bean weight (100GBW) $(\mathrm{g})$, considered as $[(\mathrm{BWP} \times 100) / \mathrm{NBP}]$; bean index $(\mathrm{BI})(\%)$, considered as [(BWP / GPW $) \times 100]$; green pod yield (GPY) $\left(\mathrm{kg} \mathrm{ha}^{-1}\right)$, total weight of pods harvested from plants in the evaluation area of the plot; green bean yield (GBY) $\left(\mathrm{kg} \mathrm{ha}^{-1}\right)$, total weight of beans harvested in the evaluation area of the plot. NBP, GPW, BWP, 100GBW, and BI were measured based on the sample of five pods collected for the GPL measurement.

The data were subjected to analysis of variance using the genetic-statistical model:

$Y_{i j k}=\mathrm{m}+b_{k}+g_{i}+a_{j}+g a_{i j}+e_{i j k}$

where, $Y_{i j k}=$ observations referring to the $i$-th genotype in the $j$-th environment in the $k$-th replication (block); $\mathrm{m}=$ general mean; $b_{k}=$ effect of the $k$-the replication; $g_{i}=$ effect of the $i$-th genotype $(i=1,2, \ldots, 20)$, considered as random; $a_{j}=$ effect of the $j$-th environment $(j=1,2, \ldots, 5)$, considered as random; $g a_{i j}=$ effect of the interaction between the $i$-th genotype and the $j$-th environment, considered as random; and $e_{i j k}=$ experimental error of $Y_{i j k}$.

The estimates of Pearson's phenotypic correlations $\left(r_{f}\right)$ between characters were carried out using the following expression:

$r_{f}=\frac{\sum_{i=1}^{n}\left(x_{i}-\bar{x}\right)\left(y_{i}-\bar{y}\right)}{\sqrt{\sum_{i=1}^{n}\left(x_{i}-\bar{x}\right)^{2} \cdot \sqrt{\sum_{i=1}^{n}\left(y_{i}-\bar{y}\right)^{2}}}}$

for which $\chi_{1}, \chi_{2}, \ldots, \chi_{\eta}$ an $\mathrm{d}_{1}, \mathrm{y}_{2}, \ldots, \mathrm{y}_{\eta}$ were obtained from the matrix of means of the genotypes in the different environments. These estimates were tested at $1 \%$ and $5 \%$ probability by the $\mathrm{t}$ test.

The relative importance of the characters was estimated by principal component analysis (SINGH, 1981). The removal of some characters was carried out by discarding those that presented the least contribution to explain the global variance of the data of the genotypes evaluated. Thus, the index was developed disregarding the characters that presented the highest weighting values in the components with the lowest eigenvalues. 
Then, analysis of factors was carried out using the following model:

$X_{j}=l_{j 1} F_{1}+l_{j 2} F_{2}+\ldots+l_{j m} F_{m}+\varepsilon_{j}$

where, $X_{j}=$ estimated character in each plot with $j=1,2, \ldots$ $\mathrm{v} ; l_{j k}=$ factorial load for the $j$-th character associated to the $k$-th factor, with $\mathrm{k}=1,2, \ldots \mathrm{m} ; \mathrm{F}_{\mathrm{k}}=k$-th common factor; and $\varepsilon_{j}=$ specific factor associated to the $j$-th character.

The initial factorial load was given by: $1_{j \mathrm{k}}=\lambda^{2}{ }_{i j} V_{i j}$, where $\lambda_{i j}$ is the $i$-th eigenvalue higher than 1 obtained from the phenotypic correlation matrix; and $V_{i j}$ is the $j$-th value of the $i$-th vector, with $j=$ number of characters; and $k$ is the number of factors. The communality was represented by:

$C_{j}=l_{j 1}^{2}+l_{j 2}^{2}+\cdots+l_{j m}^{2}$

The final number of factors considered for the grouping of characters was given by the number of eigenvalues equal or higher than 1. The grouping of characters was carried out considering the magnitudes and signs of the values found in the communalities, the first factorial loads and, mainly, the final factorial load obtained after rotation, which indicates that these characters present high correlation and can be grouped in a same factor. The extraction of factorial loads was carried out by principal component analysis, and the factors were established by the varimax rotation method (CRUZ; CARNEIRO; REGAZZI, 2014).
The scores used for the development of indexes were obtained by equation systems:

$F_{k}=\mathrm{b}_{1 \mathrm{k}} \mathrm{X}_{1}+\mathrm{b}_{2 \mathrm{k}} \mathrm{X}_{2}+\ldots+\mathrm{b}_{\mathrm{jk}} \mathrm{X}_{\mathrm{j}}$

where $b_{j k}(\mathrm{k}=1.2, \ldots \mathrm{m}, \mathrm{j}=1.2 \ldots \mathrm{v})=$ element of the matrix $\beta$, given by: $\beta\left(\Lambda \Lambda^{\prime}\right)^{-1} \Lambda(\Lambda=$ matrix of dimensions $m \times$ $v$ of the final rotated factorial loads; and $\beta=$ matrix of dimension $m \times v$ of weighting coefficients of characters to obtain the scores of the factors.

All analyses were carried out using the GENES Genetic and Statistical program (CRUZ, 2013).

\section{RESULTS AND DISCUSSION}

The analysis of variance showed significant differences $(p<0.01)$ for the effects of genotypes and environments on all characters (Table 2). This indicates differences in the relative responses of the genotypes for the characters evaluated, and that the genotypes had different performances in the different environments used. The effect of the interaction between genotypes and environments was significant for all characters, except for plant height. Thus, the genotypes presented different responses for the characters studied in the different environments evaluated.

Table 2 - Analyses of variance for number of days for the beginning of flowering (NDF), number of days for maturation (NDM), plant height (PH), green pod length (GPL), number of beans per green pod (NBP), green pod weight (GPW), bean weight per green pod (BWP), bean index (BI), one hundred green bean weight (100GBW), green pod yield (GPY), and green bean yield (GBY) of 20 cowpea genotypes grown for green bean production in five locations in the state of Ceará, Brazil, in 2018

\begin{tabular}{|c|c|c|c|c|c|c|c|}
\hline Source of variation & $\mathrm{DF}$ & $\mathrm{NDF}$ & NDM & $\mathrm{PH}$ & GPL & NBP & GPW \\
\hline Blocks & 3 & 2.576 & 1.816 & 36.306 & 5.022 & 8.691 & 2.265 \\
\hline Genotype (G) & 19 & $12.226 * *$ & $15.577 * *$ & $6.295^{* *}$ & $10.5317 * *$ & $16.575^{* *}$ & $21.363 * *$ \\
\hline Environment (E) & 4 & $1007.83^{* *}$ & $820.896 * *$ & $2150.51^{* *}$ & $31.663 * *$ & $69.928 * *$ & $38.070^{* *}$ \\
\hline $\mathrm{G} \times \mathrm{E}$ & 76 & $4.218^{* *}$ & $6.242 * *$ & $9.437^{\mathrm{ns}}$ & $2.931 * *$ & $3.019 * *$ & $2.319 * *$ \\
\hline Residue & 297 & 2.418 & 2.387 & 8.640 & 1.835 & 2.107 & 1.526 \\
\hline Mean & & 43.5 & 56.3 & 23.45 & 21.38 & 14.31 & 7.32 \\
\hline CV (\%) & & 3.6 & 2.7 & 15.5 & 6.3 & 10.1 & 16.9 \\
\hline Source of variation & $\mathrm{DF}$ & BWP & $\mathrm{BI}$ & 100GBW & GPY & GBY & \\
\hline Blocks & 3 & 0.663 & 174.169 & 20.011 & 1894760.6 & 368832.1 & \\
\hline Genotype (G) & 19 & $5982 * *$ & $380.397 * *$ & $355.742 * *$ & $1911194.3 * *$ & $828533.9 * *$ & \\
\hline Environment (E) & 4 & $8726^{* *}$ & $720.694 * *$ & $89.670 * *$ & $25135715.4^{* *}$ & $9905440.7 *$ & \\
\hline $\mathrm{G} \times \mathrm{E}$ & 76 & $0.699 *$ & $60.370 * *$ & $22.891 *$ & $533190.4 * *$ & $248812.9 * *$ & \\
\hline Residue & 297 & 0.520 & 37.20764 & 15.476 & 349726.1 & 158262.3 & \\
\hline Mean & & 5.07 & 70.44 & 35.710 & 1489.0 & 926.45 & \\
\hline $\mathrm{CV}(\%)$ & & 14.2 & 8.7 & 11.1 & 39.7 & 32.9 & \\
\hline
\end{tabular}

$\mathrm{DF}=$ degrees of freedom; $\mathrm{CV}=$ coefficient of variation; ${ }^{* *}=$ significant at $\mathrm{p}<0.01,{ }^{*}=$ significant at $\mathrm{p}<0.05$, and ${ }^{\mathrm{ns}}=$ not significant by the $\mathrm{F}$ test 
The coefficients of variation were low for most characters, denoting a high reliability for the estimates generated. In addition, they are consistent with estimates observed in other cowpea studies focused on green bean production (RAMOS et al., 2015; SILVA et al., 2013; SOUSA et al., 2015). The highest coefficients of variation were found for green pod yield (GPY) and green bean yield (GBY). This result has two possible explanations: 1) yield is a complex character controlled by several genes with possible allelic and genic interactions, since it is highly affected by the environment and edaphoclimatic variables (light, soil moisture, relative air humidity, and temperature) that are critical during the formation and development of cowpea seeds, resulting in intra and inter-block variations; 2) the two yields (green pods and beans) presented high moisture, which may have decreased differently during the transport for measurements in the laboratory, since some tests were conducted in specific sites, requiring transport of the material to the laboratory for measurements.

The correlation analyses showed that cultivars with earlier maturation tend to present lower plant heights, since the correlation of NDF was positive to NDM, and negative to $\mathrm{PH}$ (Table 3 ).

Oliveira et al. (2017), evaluated the genotypic gain in simultaneous selection for cowpea production and other characters and found high and positive correlation estimates between number of days for beginning of flowering and number of days for maturation. Andrade $e t$ al. (2010), reported that the selection of cowpea genotypes for green bean production is easier when it is possible to indirectly select genotypes through characters measured earlier. Therefore, NDF is a good indicator in a breeding program to select cowpea genotypes that present plants small and early cycle, phenotypes that are desirable for high- and low- technology productions.

The high positive correlation between GBY and GPY denotes that GPY may be the component that most contributed to the GBY, and that the selection of genotypes with higher green pod yield may increase green bean yield. Production is a complex character affected by several others; thus, information about these correlations assists in the identification of important characters that affect yield (SAPARA; JAVIA, 2014). Kamara et al. (2017), reported that the identification of highly correlated characteristics can reduce the number of characteristics needed for the characterization of the germplasm.

BWP presented high correlation to GPW and 100GBW. Thus, indirect selection of plants with high GPW and 100GBW means may result in gains for BWP. This is particularly interesting for selection, since it is relatively easier to measure GPW compared to BWP, since measuring BWP requires processing the beans. Carvalho et al. (2012) report that genotypes that present high pod yield, green pod weight, and one hundred bean weight should be used to improve the cowpea bean yield.

One hundred bean weight is an important character to evaluate bean size, since size classification scales for cowpea beans are based on this character. Moreover, bean size is an important commercial characteristic, since consumers prefer green beans with large sizes (FREITAS et al., 2016).

Table 3 - Pearson's coefficients of phenotypic correlations $\left(r_{f}\right)$ for number of days for the beginning of flowering (NDF), number of days for maturation (NDM), plant height (PH), green pod length (GPL), number of beans per green pod (NBP), green pod weight (GPW), bean weight per green pod (BWP), bean index (BI), one hundred green bean weight (100GBW), green pod yield (GPY), and green bean yield (GBY) of 20 cowpea genotypes grown for green bean production in five locations in the state of Ceará, Brazil, in 2018

\begin{tabular}{lcccccccccc}
\hline & NDM & PH & GPL & NBP & GPW & BWP & BI & 100 GBW & GPY & GBY \\
\hline NDF & $0.87^{* *}$ & $-0.77^{* *}$ & $-0.25^{*}$ & 0.07 & 0.06 & -0.08 & $-0.23^{*}$ & -0.16 & 0.09 & 0.11 \\
NDM & & $-0.51^{* *}$ & $-0.28^{*}$ & 0.06 & 0.06 & -0.02 & -0.13 & -0.08 & -0.06 & -0.06 \\
PH & & & $0.28^{*}$ & 0.15 & 0.16 & $0.33^{*}$ & 0.17 & $0.26^{*}$ & 0.04 & -0.02 \\
GPL & & & & $0.55^{* *}$ & $0.56^{* *}$ & $0.54^{* *}$ & $-0.29^{*}$ & 0.14 & $0.36^{*}$ & $0.31^{*}$ \\
NBP & & & & & $0.35^{*}$ & $0.42^{*}$ & -0.05 & $-0.34^{*}$ & $0.37^{*}$ & $0.33^{*}$ \\
GPW & & & & & & $0.85^{* *}$ & $-0.64^{* *}$ & $0.59^{* *}$ & $0.45^{*}$ & $0.36^{*}$ \\
BWP & & & & & & & -0.16 & $0.71^{* *}$ & $0.39^{*}$ & $0.33^{*}$ \\
BI & & & & & & & -0.11 & $-0.29^{*}$ & $-0.24^{*}$ \\
100GBW & & & & & & & & 0.09 & 0.05 \\
GPY & & & & & & & & & $0.94^{* *}$ \\
\hline
\end{tabular}

${ }^{* *}=$ significant at $\mathrm{p}<0.01,{ }^{*}=$ significant at $\mathrm{p}<0.05$, and the other pares were not significant by the $\mathrm{F}$ test 
The main component analysis showed that the percentage of accumulated variance by the three first components was $82.66 \%$ (Table 4 ). This percentage is enough to accurately interpret the data (CRUZ; CARNEIRO; REGAZZI, 2014).

The analysis of the eigenvectors with values associated with eigenvalues of the correlation matrix lower than 0.7 showed that BWP, GPW, NDM, GPL, GPY, PH, and GBY could be discard. The discard of BWP, NDM, and GBY is explained by their high correlation with GPW, NDF, and GPY, respectively (Table 3). GPL can be discarded due to its moderate correlation with NBP, since the number of beans per green pod increases as the green pod length is increased.

The analysis of factors sought to identify factors related to the characters that contribute to green bean yield. The three first principal components were used to group the characters, since they concentrated more than $80 \%$ of the total variation. The characters were grouped by the magnitudes and signs of the values found in the communalities, first factorial load and, mainly, in the final factorial load obtained after rotation. The communalities, which describe the proportion of the variance of a standardized character(GRANATO et al., 2014), presented values higher than 0.7 , except for bean index (0.571) (Table 5). Thus, the high efficiency of representation of variables by a common part was evident, except for bean index, whose low communality made it inadequate to discriminate the performance of the genotypes.
The correlations between the characters within the groups presented medium to high magnitudes, making it possible to disregard those relatively difficulty to measure or redundant within each group, such as: NDM (group 1), NBP (group 3), BWP (group 4), and GBY (group 7) (Table 5). The relative difficulty of measurement considered to discard NBP, BWP, and GBY refers to the need for processing (pod threshing) to obtain the data. The difficulty referring to NDM is firstly due to the visual analysis of color change, which requires observation of individual maturation standards of each genotype, requiring a greater attention to the pigmentation of pods of genotypes that have purple pod, for example; and secondly due to the longer time required to measure it when compared to NDF. Moreover, the discarding of NDM, BWP, and GBY for the development of the index confirms the discarding indicated by the main component analysis.

The selection indexes proposed in the present study were developed disregarding the characters that are difficult to measure and that were not adequate to discriminate the genotypes, such as the bean index. This index enables the identification of genotypes with high potential for green bean production; it was developed using the factor 3 , since it presented the highest weights and favorable signs for characters of higher importance for green bean production. The selection index recommended was: $\mathrm{I}_{3}=0.079 \mathrm{NDF}-0.083 \mathrm{PH}+0.119$ GPL + 0.034 GPW -0.176 100GBW + 0.340 GPY. The choice of characters to compose the index was consistent with that of Rodrigues et al. (2017), who considered the number of days for flowering, green pod weight, and one hundred grain

Table 4 - Estimates of eigenvalues and accumulated variance fraction explained by principal components for number of days for the beginning of flowering (NDF), number of days for maturation (NDM), plant height (PH), green pod length (GPL), number of beans per green pod (NBP), green pod weight (GPW), bean weight per green pod (BWP), bean index (BI), one hundred green bean weight (100GBW), green pod yield (GPY), and green bean yield (GBY) of 20 cowpea genotypes grown for green bean production in five locations in the state of Ceará, Brazil, in 2018

\begin{tabular}{lllllllllllll}
\hline$\lambda \mathrm{j}$ & $\lambda \mathrm{j}(\%)$ & $\mathrm{NDF}$ & $\mathrm{NDM}$ & $\mathrm{PH}$ & GPL & NBP & GPW & BWP & BI & 100GBW & GPY & GBY \\
\hline 3.949 & 35.902 & 0.280 & 0.261 & -0.329 & -0.453 & -0.402 & -0.201 & -0.361 & -0.127 & -0.085 & -0.333 & -0.271 \\
3.012 & 63.287 & 0.390 & 0.384 & -0.245 & 0.005 & 0.134 & 0.487 & 0.342 & -0.403 & 0.313 & 0.080 & 0.039 \\
2.131 & 82.661 & 0.281 & 0.111 & -0.350 & -0.074 & 0.262 & -0.165 & -0.171 & 0.093 & -0.479 & 0.446 & 0.467 \\
0.824 & 90.155 & 0.163 & 0.422 & 0.196 & -0.206 & -0.095 & -0.229 & 0.236 & 0.653 & 0.376 & 0.090 & 0.144 \\
0.638 & 95.955 & 0.208 & 0.247 & -0.060 & 0.373 & 0.467 & -0.076 & 0.084 & 0.267 & -0.308 & -0.287 & -0.523 \\
0.246 & 98.190 & 0.032 & 0.524 & 0.552 & 0.345 & -0.151 & -0.146 & -0.254 & -0.344 & -0.148 & -0.046 & 0.225 \\
0.112 & 99.211 & 0.138 & -0.012 & 0.312 & -0.185 & -0.052 & 0.063 & -0.109 & -0.063 & -0.054 & 0.701 & -0.577 \\
0.055 & 99.710 & 0.192 & -0.140 & -0.344 & 0.598 & -0.349 & -0.438 & 0.055 & -0.068 & 0.290 & 0.231 & -0.095 \\
0.025 & 99.938 & -0.622 & 0.438 & -0.368 & 0.173 & -0.187 & 0.310 & -0.182 & 0.201 & -0.038 & 0.201 & -0.102 \\
0.006 & 99.988 & -0.421 & 0.214 & -0.104 & -0.257 & 0.332 & -0.568 & 0.309 & -0.384 & 0.088 & 0.079 & -0.100 \\
0.001 & 0.000 & 0.016 & -0.022 & -0.032 & 0.024 & 0.482 & -0.028 & -0.673 & 0.005 & 0.558 & 0.006 & 0.014 \\
\hline
\end{tabular}

$\lambda_{\mathrm{j}}=$ eigenvalues, $\lambda_{\mathrm{j}}(\%)=$ percentage of accumulated variance 
Table 5 - Communalities and first and final factorial loads estimated for number of days for the beginning of flowering (NDF), number of days for maturation (NDM), plant height (PH), green pod length (GPL), number of beans per green pod (NBP), green pod weight (GPW), bean weight per green pod (BWP), bean index (BI), one hundred green bean weight (100GBW), green pod yield (GPY), and green bean yield (GBY) of 20 cowpea genotypes grown for green bean production in five locations in the state of Ceará, Brazil, in 2018

\begin{tabular}{lcccccccc}
\hline \multirow{2}{*}{ Caracter } & \multirow{2}{*}{ Communality } & \multirow{2}{*}{ Group } & \multicolumn{3}{c}{ First load Factors } & \multicolumn{3}{c}{ Final load Factors } \\
\cline { 4 - 9 } & & & 1 & 2 & 3 & 1 & 2 & 3 \\
\hline NDF & 0.935 & \multirow{2}{*}{1} & 0.556 & 0.677 & 0.410 & -0.046 & 0.966 & -0.028 \\
NDM & 0.840 & & 0.519 & 0.667 & 0.162 & -0.190 & 0.830 & -0.125 \\
\hline PH & 0.870 & 2 & -0.654 & -0.425 & -0.511 & -0.234 & -0.903 & 0.007 \\
\hline GPL & 0.822 & \multirow{2}{*}{3} & -0.900 & 0.009 & -0.108 & -0.428 & -0.594 & 0.535 \\
NBP & 0.839 & & -0.799 & 0.133 & -0.383 & -0.280 & -0.473 & 0.855 \\
\hline GPW & 0.933 & \multirow{2}{*}{4} & -0.699 & 0.846 & -0.241 & -0.912 & -0.210 & 0.238 \\
BPW & 0.930 & & -0.718 & 0.594 & -0.250 & -0.860 & -0.157 & 0.407 \\
\hline BI & 0.571 & 5 & -0.252 & -0.699 & 0.136 & 0.485 & -0.559 & 0.152 \\
\hline 100GBW & 0.812 & 6 & -0.168 & 0.543 & -0.700 & -0.850 & -0.045 & -0.296 \\
\hline GPY & 0.881 & \multirow{2}{*}{7} & -0.661 & 0.138 & 0.651 & 0.008 & -0.036 & 0.938 \\
GBY & 0.798 & & -0.538 & 0.068 & 0.681 & 0.110 & 0.006 & 0.864 \\
\hline
\end{tabular}

Table 6 - Mean values of characters that compose the selection index — number of days for the beginning of flowering (NDF), green pod weight (GPW), green pod length (GPL), one hundred green bean weight (100GBW), green bean yield (GPY), and plant height (PH) - and, scores generated from the index for 20 cowpea genotypes grown for green bean production in five locations in the state of Ceará, Brazil, in 2018

\begin{tabular}{|c|c|c|c|c|c|c|c|}
\hline \multirow{2}{*}{ Genotypes } & \multicolumn{6}{|c|}{ Mean values } & \multirow{2}{*}{ Scores IR** } \\
\hline & NDF & GPW & GPL & 100GBW & GPY & $\mathrm{PH}$ & \\
\hline MNC05-847B-123 & 43.65 & 7.21 & 20.82 & 35.87 & 1951.70 & 24.43 & 661.41 \\
\hline MNC00-595F-27 & 44.45 & 6.85 & 21.98 & 31.55 & 1850.25 & 22.18 & 628.05 \\
\hline MNC99-541F-15 & 43.10 & 7.08 & 21.18 & 36.76 & 1790.95 & 26.20 & 606.44 \\
\hline MNC05-835B-16 & 43.40 & 7.40 & 21.78 & 35.29 & 1687.65 & 21.10 & 572.11 \\
\hline MNC00-595F-2 & 43.45 & 7.03 & 21.43 & 34.27 & 1657.00 & 21.18 & 561.81 \\
\hline Paulistinha & 42.90 & 8.74 & 22.18 & 39.76 & 1651.40 & 25.74 & 558.67 \\
\hline MNC05-847B-126 & 43.20 & 6.77 & 20.94 & 32.64 & 1611.90 & 22.99 & 546.53 \\
\hline MNC05-835B-15 & 43.55 & 6.73 & 21.14 & 33.92 & 1599.80 & 21.78 & 542.34 \\
\hline BRS Aracê & 43.50 & 6.51 & 20.91 & 31.29 & 1488.20 & 20.44 & 504.93 \\
\hline BRS Guariba & 42.50 & 6.57 & 19.95 & 38.96 & 1492.85 & 23.98 & 504.68 \\
\hline MNC00-586F-303-9 & 43.05 & 8.32 & 21.77 & 38.78 & 1420.15 & 24.78 & 480.24 \\
\hline MNC05-841B-49 & 44.65 & 6.69 & 20.80 & 32.67 & 1356.20 & 20.39 & 459.90 \\
\hline Pingo-de-Ouro-1-2 & 43.05 & 7.83 & 20.13 & 41.29 & 1359.70 & 24.25 & 459.08 \\
\hline MNC99-510F-16-1 & 43.90 & 7.98 & 21.65 & 38.75 & 1300.55 & 23.34 & 439.75 \\
\hline BRS Tumucumaque & 41.85 & 7.66 & 22.76 & 44.28 & 1295.45 & 24.42 & 436.91 \\
\hline MNC02-701F-2 & 44.15 & 6.61 & 21.57 & 31.51 & 1006.25 & 24.04 & 340.86 \\
\hline BRS Xiquexique & 43.85 & 6.23 & 20.80 & 31.03 & 749.80 & 25.06 & 253.54 \\
\hline Azulão-MS* & 45.25 & 10.42 & 22.56 & 39.74 & 1871.65 & 23.04 & 634.07 \\
\hline Sempre Verde-CE* & 43.70 & 7.92 & 21.65 & 38.11 & 1604.70 & 25.75 & 543.05 \\
\hline Vagem Roxa-THE* & 42.60 & 5.85 & 21.76 & 27.70 & 1033.95 & 24.02 & 350.83 \\
\hline
\end{tabular}

${ }^{*}$ Control ${ }^{* *} \mathrm{IR}=$ scores obtained from the selection index 
weight as characters of primary importance for the prediction of genetic gains in cowpea plants.

The genotypes indicated for the green bean production were recommended based on the scores generated by the selection index for each genotype evaluated (Table 6).

Based on these values, the genotypes with the best performances for green bean production were the line MNC05847B-123 and the cultivar Azulão-MS, followed by the lines MNC00-595F-27, MNC99-541F-15, MNC05-835B-16, and MNC00-595F-2. The line MNC05-847B-123 was superior to all controls, whereas the other lines (MNC00-595F-27, MNC99-541F-15, MNC05-835B-16, and MNC00-595F-2) were superior only to the commercial control (Azulão-MS). Moreover, the lines MNC05-847B-123, MNC00-595F27, MNC05-835B-16, and MNC00-595F-2 are among the genotypes with best performances from the Verde commercial subclass (Table 1). This subclass presents green integument and cotyledons, which confer it a higher green color postharvest preservation capacity than the other commercial subclasses and indicate a high potential for the green bean market. The results showed that these genotypes are good alternatives to be recommended for green bean crops; thus, is expected that these lines will be soon available in lists of cultivars recommended for green bean production.

\section{CONCLUSIONS}

Cowpea genotypes for green bean production can be recommended using the selection index $\mathrm{I}_{3}=0.079 \mathrm{NDF}$ $-0.083 \mathrm{PH}+0.119 \mathrm{GPL}+0.034 \mathrm{GPW}-0.176$ 100GBW +0.340 GPY. The lines MNC05-847B-123, MNC00-595F27, MNC99-541F-15, MNC05-835B-16, and MNC00595F-2, and the cultivar Azulão-MS were selected by this selection index and are the most promising genotypes to be recommended for green bean production.

\section{ACKNOWLEDGEMENTS}

The authors thank the Brazilian Agricultural Research Corporation (Embrapa Mid-North) for providing financial support and the seeds used in this study; and the Foundation for Support of Scientific and Technological Development of the State of Ceará (FUNCAP) for granting study scholarships.

\section{REFERENCES}

ANDRADE, F. N. et al. Estimativas de parâmetros genéticos em genótipos de feijão-caupi avaliados para feijão fresco. Revista Ciência Agronômica, v. 41, n. 2, p. 253-258, 2010.
CARVALHO, L. C. B. et al. Phenotypic correlations between combining abilities of F2 cowpea populations. Crop Breeding and Applied Biotechnology, v. 12, n. 3, p. 211-214, 2012.

COMPANHIA NACIONAL DE ABASTECIMENTO. Acompanhamento da safra brasileira de grãos: safra 2017/2018: quinto levantamento. 2018. v. 5, p. 68-89. Disponível em: http://www.conab.gov.br/OlalaCMS/uploads/ arquivos/18_02_08_17_09_36_fevereiro_2018.pdf. Acesso em: 12 abr. 2019.

CRUZ, C. D. GENES: a software package for analysis in experimental statistics and quantitative genetics. Acta Scientiarum, v. 35, n. 3, p. 271-276, 2013.

CRUZ, C. D.; CARNEIRO, P. C.; REGAZZI, A. D. Modelos biométricos aplicados ao melhoramento genético. 3. ed. Viçosa, MG: Editora UFV, 2014. v. 2, 668 p.

FREIRE FILHO, F. R. et al. A cultura: aspectos socioeconômicos. In: DOVALE, J. C.; BERTINI, C.; BORÉM, A. (ed.). Feijão-caupi: do plantio à colheita. Viçosa, MG: Editora UFV, 2017. cap. 1, p. 9-34.

FREIRE FILHO, F. R. et al. Feijão-caupi no Brasil: produção, melhoramento genético, avanços e desafios. Teresina: Embrapa Meio-Norte, 2011. 84 p.

FREITAS, T. G. et al. Green bean yield and path analysis in cowpea landraces. Revista Caatinga, v. 29, n. 5, p. 866-877, 2016.

GRANATO, I. S. C. et al. Index selection of tropical maize genotypes for nitrogen use efficiency. Bragantia, v. 73, n. 2, p. 153-159, 2014.

KAMARA, A. Y. et al. Agronomic evaluation of cowpea cultivars developed for the African Savannas. Legume Research, v. 40, n. 4, p. 669-676, 2017.

OLIVEIRA, A. P. et al. Rendimento de feijão-caupi cultivado com esterco bovino e adubo mineral. Horticultura Brasileira, v. 19, n. 1, p. 81-84, 2001.

OLIVEIRA, D. G. et al. Genotypic gain with simultaneous selection of production, nutrition, and culinary traits in cowpea crosses and backcrosses using mixed models. Genetics and Molecular Research, v. 16, n. 3, p. 1-11, 2017.

RAMOS, D. P. et al. Avaliação de genótipos de feijão-caupi para produção de grãos verdes em Gurupi, Tocantins. Revista Verde de Agroecologia e Desenvolvimento Sustentável, v. 10, n. 5, p. 160-164, 2015.

RODRIGUES, E. V. et al. Selection of cowpea populations tolerant to water déficit by selection index. Revista Ciência Agronômica, v. 48, n. 5, p. 889-896, 2017.

SAPARA, G. K.; JAVIA, R. M. Correlation and path analysis in vegetable cowpea (Vigna unguiculata L.). International Jornal of Plants Sciences, v. 9, n. 1, p. 138-141, 2014.

SILVA, E. D. et al. Avaliação de cultivares de feijão-caupi irrigado para produção de grãos verdes em serra Talhada-PE. Revista Caatinga, v. 26, n. 1, p. 21-26, 2013. 
SILVA, K. J. D.; ROCHA, M. M.; MENEZES JÚNIOR, J. A. N. de. Socioeconomia. In: BASTOS, E. A. (ed.). A cultura do feijão-caupi no Brasil. Teresina: Embrapa Meio-Norte, 2016. cap. 1, p. 6-12.

SILVEIRA, M. A. et al. Estratégia de comercialização do feijão-caupi produzido por agricultores familiares: um estudo de caso na região leste de Goiás. Conjuntura Econômica Goiana, v. 1, n. 30, p. 36-54, 2014.
SINGH, D. The relative importance of characters affecting genetic divergence. Indian Journal of Genetics and Plant Breeding, v. 41, p. 237-245, 1981.

SOUSA, J. L. M. et al. Potencial de genótipos de feijãocaupi para o mercado de vagens e grãos verdes. Pesquisa Agropecuária Brasileira, v. 50, n. 5, p. 392-398, 2015. 